\title{
A new report of Sanbornia juniperi Pergarde ex. Barker, 1920 (Hemiptera: Aphididae) in Neotropical region
}

\section{Novo registro de Sanbornia juniperi Pergarde ex. Barker, 1920 (Hemiptera: Aphididae) na região Neotropical}

\author{
Orcial Ceolin Bortolotto ${ }^{1 *}$; Ayres de Oliveira Menezes Júnior²; \\ Carlos Roberto Sousa-Silva ${ }^{3}$
}

\begin{abstract}
This study aimed to record new observations of Sanbornia juniperi Pergarde ex. Barker, 1920 (Hemiptera: Aphididae) in the Neotropical region associated with Juniperus chinensis L. (Cupressaceae). The aphids were found in September 2010 in Londrina city ( $23^{\circ} 20$ ' 23 "S, 51 ' 12 ' 32” W, 532m), Parana state (PR), Brazil. This represents only the second report of S.juniperi in the Neotropical region, and the first report was associated with $J$. chinensis, thereby indicating that in addition to dispersion, the aphid is colonizing new hosts.
\end{abstract}

Key words: Aphids, dispersion of insects, ornamental plant, Juniperus chinensis, Cupressaceae

\section{Resumo}

O objetivo deste estudo foi registrar nova ocorrência de Sanbornia juniperi Pergarde ex. Barker, 1920 (Hemiptera; Aphididae) na região Neotropical, associado à Juniperus chinensis L. (Cupressaceae). Os pulgões foram encontrados em setembro de 2010, na cidade de Londrina, Estado do Paraná. Este é apenas o segundo registro de S. juniperi na região Neotropical, e o primeiro associado à J. chinensis, indicando que além do inseto estar em processo de dispersão, está colonizando novos hospedeiros.

Palavras-chave: Pulgões, dispersão de insetos, plantas ornamentais, Juniperus chinensis, Cupressaceae

Discente de Doutorado, Universidade Estadual de Londrina, UEL, Londrina, PR. E-mail: bortolotto.orcial@gmail.com Prof. Dr. Dept ${ }^{\circ}$ de Agronomia, UEL/CCA, Londrina, PR. E-mail: ayres@uel.br

Prof. Dr. Universidade Federal de São Carlos, UFSCar, São Carlos, SP. E-mail: dcrs@power.ufscar.br

Author for correspondence 
Juniperus chinensis L. (Cupressaceae) is native to eastern Asia, and it is widely used as an ornamental plant (DIRR, 1998). The plant height varies from small shrubs to 60-meter tall trees. Although it is native to Asia, it is distributed worldwide, and it is believed that $J$. chinensis is the most cultivated plant in gardens worldwide (RAINA et al., 2005).

Factors that may affect the aesthetics of ornamental plants include disease development and insect or other arthropod pest infestation (SHREWSBURY; HARDIN, 2003). In 2001, Sousa-Silva and Ilharco (2001) reported the first observation of Sanbornia juniperi ex. Barker, 1920 (Hemiptera: Aphididae) infesting Cupressus lusitanica Miller (Cupressaceae) in the Neotropical region. This aphid is native to the Nearctic region, and it is associated with both cupressaceae Juniperus virginiana L. and Juniperus scopulorum Sarg. in the United States (BLACKMAN; EASTOP, 1994).

However, limited data is available regarding this aphid. This aphid is characterized by a very restricted distribution worldwide. Therefore, this study aimed to document new reports of $S$. juniperi in the Neotropical region. In September 2010, the aphids were found to be associated with $J$. chinensis "variegata" at the Universidade Estadual de Londrina, Londrina city $\left(23^{\circ} 20\right.$ ' 23 ' $\mathrm{S}, 51^{\circ} 12^{\text {' }}$ 32 ” W, 532m), Parana state, Brazil. According to the Köeppen classification, the climate in the region is humid subtropical (Cfa). Aphids were observed and captured in only one tree of the local landscape. Many aphids were observed, but approximately fifty specimens were captured and collected in plastic microtubes, where they remained preserved in $70 \%$ alcohol. After this period (September), monitoring was not performed because sufficient data was gathered to identify the aphid species. The insects were examined at the Department of Ecology and Evolutionary Biology, Universidade Federal de São Carlos, São Carlos city, São Paulo state, Brazil. For this procedure, blades were made, and a stereoscopic microscope was used to indentify the aphids.
This represents the first record of $S$. juniperi in PR state and the second report in the Neotropical region; however, the first report was associated with $J$. chinensis. As the geographical distribution of this insect is very restricted, the record of this new host will be useful for monitoring occurrences, primarily because $J$. chinensis has been widely cultivated through out the world. Therefore, this new observation, which was recorded more than $400 \mathrm{~km}$ from the initial Neotropical observation (São Carlos city, São Paulo state), indicates that the insects have adapted to the region, have colonized new hosts and are dispersing. Moreover, the adaptation of this insect indicates that this aphid maybe come an important pest of $J$. chinensis and other Cupressaceae hosts. Thus, these observations suggest that additional studies of the interaction between this aphid and the plant are required.

\section{Acknowledgments}

We are grateful to CAPES for the post-graduate support of the first author.

\section{References}

BLACKMAN, R. L.; EASTOP, V. F. (Ed.). Aphids on the world's trees. An identification and information Guide. Wallingford: CAB, 1994. 986 p.

DIRR, M. A. Manual of woody landscape plants: their identification, ornamental characteristics, culture, propagation, and uses. Champaign: Stipes Publishing Company, 1998, 1187 p.

RAINA, V. K.; SRIVASTAVA, S. K.; SYAMSUNDAR, K. V. Essencial oil composition of Juniperus chinensis from the plains of northern India. Flavour and Fragrance Journal, New Jersey, v. 20, n. 1, p. 57-59, 2005.

SHREWSBURY, P. M.; HARDIN, M. R. Evaluation of predatory mite (Acari: Phytoseiidae) releases to suppress spruce spider mites, Olygonichus ununguis (Acari: Tetranychidae) on Juniper. Entomological Society of America, Lanham, v. 96, n. 6, p. 1675-1684, 2003.

SOUSA-SILVA, C. R.; ILHARCO, F. A. The presence of Sanbornia juniperi (Hemiptera: Aphididae) in Neotropical the region. Revista de Biologia Tropical, San José, v. 49, n. 2, p. 765-772, 2001. 